\title{
The effects of information asymmetry on the value of the companies listed in Tehran Stock Exchange
}

\section{Amir Hassan Ghorbani*}

M.A in Financial Management, University of Tehran, Tehran, Iran

\section{H R O N I C L E A B S T R A C T}

Article history:

Received October 26, 2012

Received in revised format

28 January 2013

Accepted 25 March 2013

Available online

March 262013

Keywords:

Asymmetric information

Trading volume flow

The Tobin's $Q$

\begin{abstract}
Information asymmetry arises when one of the parties to the contract or transaction, possesses more information than the other, provided that the former uses such information effectively when communicating with the latter. The main objective of this study was to examine the effects of information asymmetry on the value of companies. Two techniques i.e. standard deviations of returns (STDRET) and turnover (TURNOVER) were used to determine information asymmetry while the Tobin's Q was employed to determine companies' value. The population under study was all the listed companies in Tehran Stock Exchange, of which a total of 72 companies were chosen as the research sample and were studied over the period 20042009. Panel analysis technique was used in this study to analyze the collected data. The results of the study indicate information asymmetry affect the value of the companies.
\end{abstract}

\section{Introduction}

One of the negative phenomena observed in any market securities is associated with the lack of information asymmetry, leading to inappropriate economic decisions by investors. Information asymmetry arises when some people have more information than the other do, which creates an unfair advantage against others for making financial decisions. Obviously, the people who have more information will enjoy more economic interests than the others do (Harford et al., 2008). Information asymmetry between firms and investors normally makes a difference between the cost of internal and external finances so that the external financing would cost more for company. In other words, information asymmetry creates some challenges for the external financing since the people outsiders must make sure that the securities are not overpriced. Overall, it can be said that information asymmetry will have a general impact on the cost of financing (Harford et al., 2008). Therefore, financial asymmetry plays essential role on capital markets and financial reports must properly represent necessary information for investors (Sharpe, 2012; Miller \& Rock, 2012; Flannery, 2012). 
The diversity of activities in large business entities and the spread of such activities into various geographical places have made the information disclosure necessary based on different parts of business entities. Since each part of a business entity faces various kinds of risks, returns, growth opportunities, and threats, the analysis of data retrieved from these components in a combined form may be led to inappropriate economic decisions, which prevent them from informed and rational allocation of resources. Since the value of a company encompasses the value of existing equities as well, the present study aims to investigate the effects of information asymmetry on the firm value. In fact, one of the important factors in decision making process is the access to relevant and appropriate information for the case to be decided. In such cases where the needed information is distributed asymmetrically among individuals, i.e. the information is communicated unequally among people, it may create different outcomes for a single problem. Therefore, the quality of distributing information is more important for decision makers that the type of the information itself (Wang, 1993; Barney \& Hesterly, 2012).

Managements of firms are normally responsible to provide the necessary information for different interested parties including present shareholders, potential investors, etc. through stock exchange. Managers have some information about their companies' financial conditions, which is not necessarily available to investors, a case which is called information asymmetry. If managers regularly provide the information and financial data to the public it will reduce the informational gap between managers and investors. Companies whose shares are traded publicly are required to disclose financial information through proper channels and most investors depend on financial statements provided by financial managers of business units and some of them may also take into account financial experts' opinions. However, such opinions may be based on the financial statements presented by the managers of the company. Accounting process plays an important role in the valuation process because investors estimate future cash flows within the company based on accounting reports of the firm's statements. Since investors usually implement the company's cash flows to estimate its value, the valuation process is affected by financial statements used to estimate the company's cash flows (Rahnema Rudposhti \& Salehi, 2010).

There are also some cases where investors cannot trust to information reported publically through stock exchange, which is also a case of information asymmetry. In some cases, accounting instructions flexibility makes it possible for the uncommitted managers to manipulate financial statements. In fact, there were many evidences in which the firm's revenue is overestimated and it does not disclose until the next year. In such conditions, investors use incomplete information provided by managers and the securities may be priced, improperly. Although the internet has increased the possibility of providing more information to stockholders but it is unable to correct the misleading information provided by the managers. However, the passage of stricter laws is a possible solution to cope with information asymmetry by punishing those groups who are responsible to provide misleading financial information (Rahnema Rudposhti \& Salehi, 2010).

Achievement of long-term economic growth requires optimal allocation of resources at the level of the national economy. This is not possible without the existence of an efficient capital market because an efficient system for the distribution of resources plays essential role for healthy economy. The stock market as an organized and formal market is responsible for guiding and monitoring the financial system. Optimal allocation of resources in the stock market requires provision of necessary information for investors to help them make decisions, which lead to maximize their wealth. Such information is made accessible to users through the accounting system in the form of financial statements. In addition, users are able to evaluate the performance of various firms with the help of evaluation models. Evaluation models make this happens by linking accounting and financial data to the stock market value. 
For many years, researchers have developed various theoretical models to explain the firm value. The initial models often explain firm's value based on non-accounting variables but because of some difficulties, they gradually become obsolete and were replaced by other models. Measurement of the firm value is often recognized as a replacement for combining the market financial resources. The firm value, the value of economic entity, is estimated as the value of the market capital plus debt incurred due to the supervision costs and preferred stocks minus the cash inventory and cash equivalent. The firm value is an economic index representing the market value of a business and it represents the claims made by all bondholders, preferred shareholders, and common shareholders about the firm value.

The firm value is one of the important parameters used in the valuation of business, financial models, and portfolio accounting and analysis. The firm value is more comprehensive compared with the market value, which only includes equity of common shareholders. The firm value is determined as Inventory - total debt + market capital value. During the past few years, there have been tremendous efforts on investigating the effects of asymmetry information on firms' valuations. According to Ghaemi and Vatanparast (2005), investors with short investment horizons do more to find secret information before the announcement of earnings, indicating that a high level of information asymmetry is available before the announcement of dividends.

Hassani and Taheri (2012) examined the relationship between earnings management and information asymmetry based on some companies listed in Tehran Stock Exchange (TSE) over the period of 2005-2010. The study implemented qualified instances by taking into account all limitations and necessary criteria. They concluded that there was not any relationship between earning management and information asymmetry in selected firms listed on TSE.

Kazemi and Rahmani (2012) determined the relationship between informational asymmetry and capital cost using the information of 109 firms listed in TSE over the period 2005-2010 and reported a positive and significant relationship between informational asymmetry and capital cost. Their results indicated that when capital markets were competitive, there was not any significant relationship between informational asymmetry and capital cost. However, when markets were partially competitive there was a significant relationship between informational asymmetry and capital cost.

Clarke et al. (2004) studied the relationship between firm diversification and asymmetric information empirically based on metrics drawn from the market microstructure literature and reported that the average diversified firm in their sample had less severe asymmetric information problems than a similarly constructed portfolio of stand-alone firms chosen to approximate the segments of the conglomerate.

\section{The proposed study}

The proposed study of this paper investigates whether information asymmetry influences firm's value or not. The population of this study includes all companies listed in TSE over the period 2004-2009. The proposed study of this paper uses systematic elimination method to select the research sample where all firms in the population with the following requirements have been included in the samples and the remaining companies that did not meet these requirements,

1. The companies' fiscal year should end in March $19^{\text {th }}$ and they should not have changed their fiscal year in the period under study.

2. The companies' shares should be traded over the period under study.

3. The data related to these companies must be available. 
Given the above requirements, a total number of 72 companies were included in the sample for a sixyear period, amounting to 432 year-company. The information asymmetry was examined in the present study as the independent variable and was measured through turnover (TURNOVE R) and the standard deviation of returns (STDRET). In addition, the dependent variable is a variable that changes under the influence of the independent variables. The dependent variable of this study was the firm value measured by the Tobin’s Q (Gilligan \& Krehbiel, 1989; Chiappori \& Salanié, 2000).

\subsection{Data collection and analysis}

The data needed in the present study were collected through RAHAVARD NOVIN Software, the official website of Tehran Stock Exchange, and TADBIR PARDAZ Software. In cases where a part of the required data was not accessible by the above software, the financial statements of the sample companies were used. In addition, library resources such as different books, weekly and monthly magazines, books published by research centers, students' theses and dissertations, electronic databases, and the information available in the Tehran Stock Exchange Organization were used to collect the data related to the companies under study.

\subsection{Operational definition of variables under study}

Information asymmetry and the firm value were explored in this study as research variables. Tobin's Q Ratio, is the market value of a company's assets divided by their replacement value. In addition, the information asymmetry was measured through turnover (TURNOVER) and the standard deviation of returns (STDRET). Turnover (TURNOVER) refers to annual turnover divided by the number of stocks issued by a company.

$$
\text { TOR } \frac{T V}{S}
$$

where, TV represents turnover, $S$ is the number of stocks issued, and TOR is the turnover ratio. Turnover is expressed as an indicator to determine the heterogeneity of beliefs about the value of a given company. Accordingly, turnover is used as an indicator of the lack of available information about the company. Another method used to determine the information asymmetry is the standard deviation of daily stock returns (STDRET). In the present study, STDRET was used to determine the accuracy of the estimations. Standard deviation is a measure of uncertainty that increases the level of information asymmetry within a firm excessively. Table 1 presents the estimation of measures of central tendency such as mean and measures of dispersion such as standard deviation, kurtosis and skewness for different variables. The greater values of mean than those of the median show the existence of outlier points in the data as the mean is influenced by such large values. In such cases, the data distribution is skewed toward the right side of the curve. For instance, distribution curve of STDRET, Tobin's Q, and TURNOVER is skewed to the right. No variable is skewed to the left. For some variables, the mean and median have very close values, leading to the symmetrical distribution of variables. Almost all variables except for those mentioned especially the dependent variable logarithm are relatively symmetrical. This is an important feature because symmetry is one of the features of the normal distribution that will be discussed below.

\section{Table 1}

Descriptive statistics

\begin{tabular}{lllllllll}
\hline Variables & Valid obs. & Mean & Median & SD & Skewness & Kurtosis & Min & Max \\
\hline STDRET & 432 & 0.2725 & 0.0784 & 1.40950 & 12.258 & 165.895 & 0.00 & 22.27 \\
Tobin's Q & 432 & 1.6379 & 1.2768 & 1.04649 & 3.336 & 17.203 & 0.50 & 10.19 \\
Turnover ratio & 432 & 1.7146 & 0.2016 & 15.31774 & 18.098 & 351.535 & 0.00 & 303.3 \\
Tobin's Q logarithm & 432 & 0.3662 & 0.2444 & 0.46075 & 1.033 & 0.815 & -0.40 & 2.09 \\
STDRET logarithm & 432 & -2.5164 & -2.5460 & 1.29080 & -0.971 & 3.792 & -8.52 & 0.73 \\
TURNOVER logarithm & 432 & -1.8704 & -1.6015 & 2.17298 & -0.946 & 1.816 & -10.04 & 3.21 \\
\hline
\end{tabular}




\subsection{Normal distribution of the dependent variables}

Normality of the regression model residuals is one of regressive assumptions of regression model that indicated the validity of regression tests. In this study, Kolmogorov-Smirnov Test was employed to examine normal distribution of the dependent variables since the normality of the dependent variables is dependent on the model residuals (i.e. the difference between the estimated values of the real values). As a result, it is necessary to check the normality of the dependent variable before estimating the control parameters. For the cases in which the normality requirement is not met, proper solution must be found (such as changing the variables). The null and the alternative hypotheses of the present study are written as follows:

- $H_{0}$ : Data related to the dependent variable follow a normal distribution.

- $H_{1}$ : Data related to the dependent variable do not follow a normal distribution.

Since the level of significance for the STDRET, Tobin's Q, and TURNOVER is less than 0.05 for the period under study, the null hypothesis is rejected for the above variables. In other words, distribution of variables is not normal in different years. However, the level of significance for the logarithm of these variables is greater than 0.05 for the whole period so they follow a normal distribution (i.e. the combination of normally distributed data is also normal).

Table 2

Results of Kolmogorov-Smirnov Test

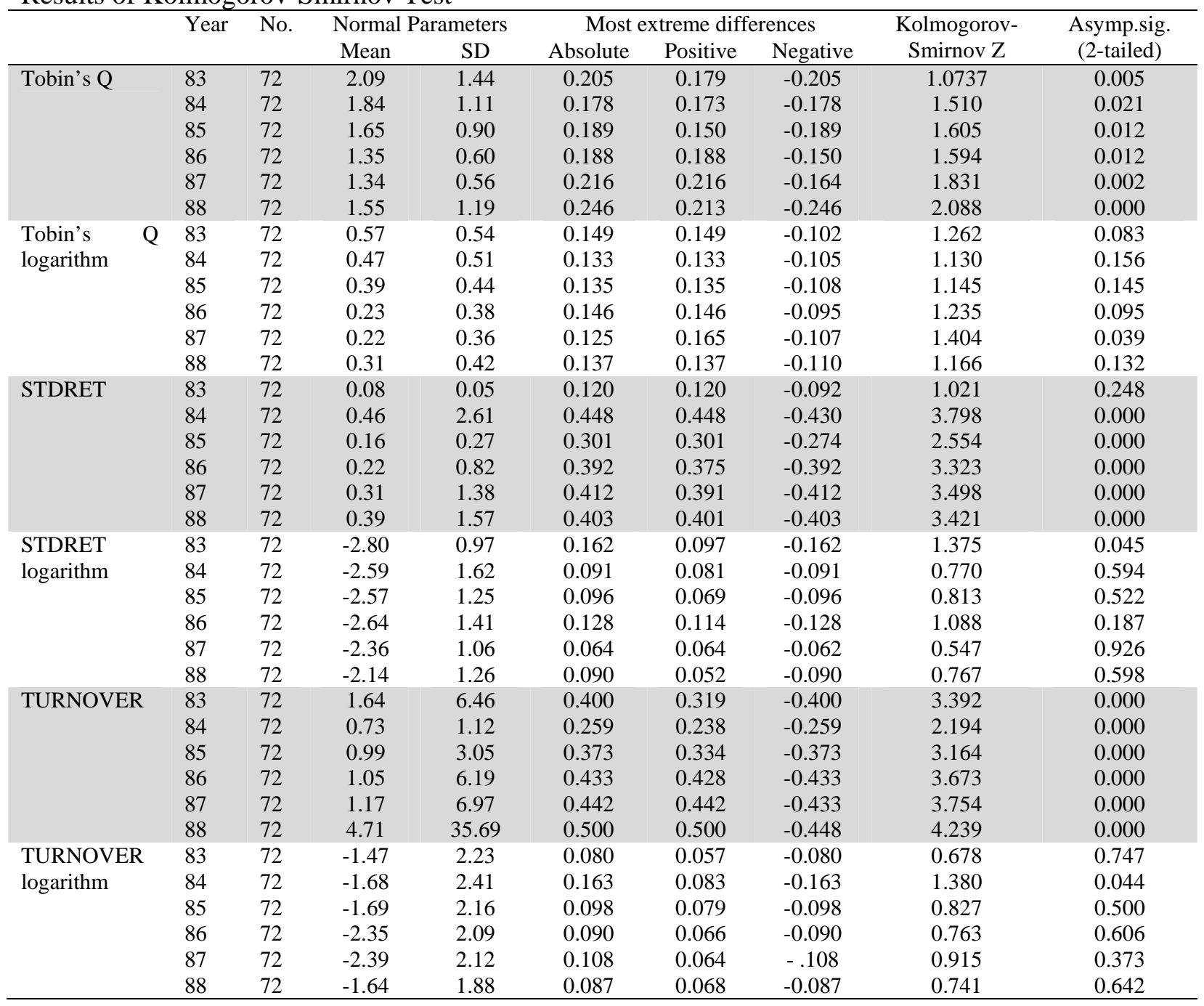


Panel analysis without fixed effects, with fixed effects, and random effects was used to analyze the data. Limer (Chaw) Test and Houseman Test were employed to examine the model's fitness with fixed or random effects (Accounting Standards, 2005; Aflatouni et al., 2010).

\section{The results of testing the research hypotheses}

The proposed model of this paper uses the following regression model to test the hypotheses of this survey,

$$
\operatorname{Ln}(Q-\text { tobin })=\beta_{0}+\beta_{1} X_{11 i t}+\beta_{2} X_{12 i t}+\varepsilon_{i t}
$$

The null hypothesis and the alternative hypothesis in the model are as follows:

$$
\left\{\begin{array}{l}
H_{0}: \beta_{1}=\beta_{2}=0 \quad \text { The model is not significant. } \\
H_{1}: \beta_{i} \neq 0 \quad i=1,2 \text { The model is significant. }
\end{array}\right.
$$

Table 3 shows the results of the panel analysis for the research hypotheses. The t value for STDRET is 2.49 (positive and significant) and for the ratio of TURNOVER to the stocks is 5.55 (positive and significant). The $t$ value for the intercept is 9.89, indicating that the null hypothesis is rejected at the $95 \%$ level of confidence.

\section{Table 3}

\begin{tabular}{|c|c|c|c|c|c|c|c|c|}
\hline \multirow{2}{*}{ Parameters } & \multirow{2}{*}{ Estimation } & \multirow{2}{*}{ t-value } & \multirow{2}{*}{ Results } & \multicolumn{2}{|c|}{ Significance value } & \multirow{2}{*}{ Selection } & \multirow{2}{*}{$\begin{array}{l}\text { Coefficient of } \\
\text { determination }\end{array}$} & \multirow{2}{*}{$\begin{array}{l}\text { Durbin- } \\
\text { Watson }\end{array}$} \\
\hline & & & & Chaw & Housman & & & \\
\hline Constant & 0.26 & 9.89 & Significant & \multirow{3}{*}{0.000} & \multirow{3}{*}{1.00} & \multirow{3}{*}{$\begin{array}{l}\text { Random } \\
\text { effects }\end{array}$} & \multirow{3}{*}{0.07} & \multirow{3}{*}{1.7} \\
\hline STDRET & 2.49 & 0.95 & Significant & & & & & \\
\hline TURNOVER & 5.55 & 4.14 & Significant & & & & & \\
\hline
\end{tabular}

Results of panel analysis

Chaw (Limer) Test was employed to determine whether the model with fixed effects is more suitable or the pooled model is more preferable. In other words, Chaw (Limer) Test was used to examine the following hypotheses:

$\left\{\begin{array}{l}H_{0} \text { : The pooled model is more suitable. } \\ H_{1} \text { :The model with fixed effects is more suitable. }\end{array}\right.$

As shown in Table 3, the level of significance to test the suitability of the model with fixed effects is 0.000; suggesting that the null hypothesis is rejected. As a result, the model with fixed effects is more suitable than the pooled model.

In addition, the model with random effects is compared with the model with fixed effects by Houseman Test. First, the model with random effects was estimated and then it was tested by Houseman Test. The null hypothesis and the alternative hypothesis were examined by Houseman Test as follows,

$$
\left\{\begin{array}{l}
H_{0} \text { : The pooled model is more suitable. } \\
H_{1} \text { :The model with fixed effects is more suitable. }
\end{array}\right.
$$

The level of significance for the Houseman Test is 1.000; indicating that the model with random effects model is appropriate. Besides, the results of testing the model with random effects indicate that the null hypothesis is rejected at the $95 \%$ level of confidence. In other words, the model is significant at the $95 \%$ level of confidence. 
The value of determination coefficient is 0.07 , showing that almost $7 \%$ of the changes in the dependent variable is explained by the independent variables. In addition, the Watson-Durbin value is 1.7 (See Table 3). The $t$ value for STDRET is 0.94 (in significant) and for the ratio of TURNOVER to the stocks is 4.14 (positive and significant). The $t$ value for the intercept is 4.20 , indicating that the null hypothesis is rejected at the $95 \%$ level of significance.

\section{Conclusions and suggestions}

The present study has examined the effects of information asymmetry on the firm value within a 6year period. The findings of the study, generally, have indicated that there was a positive and significant relationship between information asymmetry and the firm value. Accordingly, the results of different tests have performed in this study indicate that information asymmetry affects the firm value. The following suggestions are offered based on the results of the study:

1. The population in the present study included all industries. Future research can focus on specific industries in order to control the effects of industries on the results obtained.

2. The present study used STDRET and TURNOVER to measure information asymmetry. Future researchers may use other measures such as the differences in prices offered for the purchase and the sale of stocks.

3. The present study investigated the effect of information asymmetry on the firm value. Further research can examine possible effects of other variables such as income management, cash holdings, corporate leadership, and the corporate risks.

\section{References}

Aflatouni, A., \& Nikbakht, L. (2010). The application of econometrics in accounting, financial management and economics research. Tehran: Termeh Publications, [In Persian].

Accounting Standards (2007). Standard No. 25: p. 520: The Auditing Organization. Tehran, Iran.

Barney, J.B., \& Hesterly, W.S. (2012). Strategic management and competitive Advantage. concepts and cases. Fourth edition: Pearson Press.

Chiappori, P. A., \& Salanié, B. (2000). Testing for asymmetric information in insurance markets. Journal of Political Economy, 108(1), 56-78.

Clarke, J. E., Fee, C. E., \& Thomas, S. (2004). Corporate diversification and asymmetric information: evidence from stock market trading characteristics. Journal of Corporate Finance, 10(1), 105-129.

Flannery, M. J. (2012). Asymmetric information and risky debt maturity choice.The Journal of Finance, 41(1), 19-37.

Gilligan, T. W., \& Krehbiel, K. (1989). Asymmetric information and legislative rules with a heterogeneous committee. American Journal of Political Science, 459-490.

Ghaemi, M.H., \& Vatanparast, M. (2005). Investigating the role of accounting information in reducing information asymmetry in the Tehran Stock Exchange. Journal of Accounting and Auditing Review,12(41),85-103.

Harford, J., Mansi, S. A., \& Maxwell, W. F. (2008). Corporate governance and firm cash holdings in the US. Journal of Financial Economics, 87(3), 535-555.

Hassani, M., \& Taheri, F. (2012). The role of earnings management and dividend announcement in explanation of information asymmetry: Evidence from Tehran Stock Exchange. Management Science Letters, 2(7), 2537-2544.

Kazemi, H., \& Rahmani, F. (2012). Relationship between information asymmetry and cost of capital. Management Science Letters, 3(1), 321-328.

Keller, G. (2011). Statistics for management and economics. South-Western Pub.

Miller, M. H., \& Rock, K. (2012). Dividend policy under asymmetric information.The Journal of Finance, 40(4), 1031-1051. 
Rahnema Rudposhti, F., \& Salehi, A.K. (2010). Financial and accounting schools and theories $\left(1^{\text {st }}\right.$ Edition). Tehran: Islamic Azad University (Central Tehran Branch).

Sharpe, S. A. (2012). Asymmetric information, bank lending, and implicit contracts: A stylized model of customer relationships. The Journal of Finance,45(4), 1069-1087.

Wang, J. (1993). A model of intertemporal asset prices under asymmetric information. The Review of Economic Studies, 60(2), 249-282. 